\title{
EFFECT OF ECOLOGICAL FACTORS ON THE ZONATION OF WETLAND VEGETATION
}

\author{
RICHARD HRIVNÁK \\ Institute of Botany, Slovak Academy of Sciences \\ Dúbravská cesta 14, Bratislava, SK-845 23, Slovakia \\ e-mail: richard.hrivnak@savba.sk \\ (Received: March 3, 2004. Accepted: June 25, 2004)
}

\begin{abstract}
The influence of some ecological factors to aquatic and marsh vegetation was studied during 1998-2000. Three basic vegetation units (Caricetum buekii, Typhetum latifoliae and Ceratophylletum submersi) and three transitional communities were defined in the belt transect, which was established along the moisture gradient. The content of available soil nutrients in individual vegetation types differed only in case of the Ceratophyllum submersum community, where a higher magnesium and nitrogen content accumulated due to specific environmental conditions. Water and marsh vegetation is usually characterised by a pronounced spatial and temporal dynamics. In the studied area, its zonation was dependent from the terrain morphology, and both depth and duration of floods. The fluctuation of ground and surface water table during a three-year period caused changes in the occurrence and cover of several species (e.g. Carex buekii, Typha latifolia, aquatic macrophytes). Pronounced changes in the cover of some species occurred even within a single vegetation season due to the long-term sink of water table below the ground surface.
\end{abstract}

KEY WORDS: hydrology, floristic and vegetation changes, species-environment relationships, wetland, zonation of vegetation.

\section{INTRODUCTION}

Wetland vegetation is very sensitive to changes of environmental condition. The ecological studies of vegetation changes are realised in various time and spatial scales. They study effect of environmental conditions on vegetation composition. The long-term studies were made in countries with traditional ecology-vegetation research (e.g. Rintanen 1996; Busch et al. 1998; Owen 1998; Berlin et al. 2000; Leendertse et al. 1997; Solińska-Górnicka and Symonides 2001; Schaminée et al. 2002). The knowledge about evolution of land during a few hundreds or thousends of years is important for better understanding of these processes. This information is provided by palynological study of deposits in the residual channel and flood basin or mires (cf. e.g. de Klerk et al. 1997; Peteet et al. 1998; van der Knapp and van Leeuwen 1997). The shortterm studies focus on relationship between plants or vegetation and environmental conditions. Among them, the water-level fluctuation, duration and depth of flooding, drought, soil and water chemistry, type of sediment and flow velocity belong to the most studied ones (cf. e.g. Papastergiadou and Babalonas 1993a, b; van der Valk et al. 1994; David 1996; Sanchez et al. 1998; Moore et al. 1999; Budelsky and Galatowitsch 2000; Bledsoe and Shear 2000; Casanova and Brock 2000; Riis and Hawes 2002; Baatrup-
Pedersen and Riis 2003). Recently, specific problems arose by human impact to vegetation and land use (e.g. Isachenko 1996; Mesleard et al. 1999; Galatowitsch et al. 2000; Clarke and Baldwin 2002; Hansel-Welch et al. 2003) as well as the global, mainly climatic changes (e.g. Simas et al. 2001; Pahl-Wostl et al. 2002; Humphries and Baldwin 2003).

In the territory of Slovakia, relationship between wetland vegetation and environment was studied in the western part, especially in the catchment area of the Morava river (Balátová-Tuláčková 1968; Banásová et al. 1994a, b; Valachovič 1995; Jarolímek et al. 1999, 2000, 2001a, b; Šeffer et al. 1999).

The aims of the study were: (i) to characterise the zonation of vegetation along a belt transect, (ii) to characterise annual and seasonal dynamics of vegetation, (iii) to detect the influence of chosen ecological factors upon the floristical composition and zonation of the vegetation.

\section{MATERIAL AND METHODS}

\section{Study site}

Transect was located in the Central Slovakia, between Zvolen and Lieskovec (latitude $48^{\circ} 34.4452^{\prime} \mathrm{N}$, longitude $19^{\circ} 10.2258^{\prime} \mathrm{E}$; the square of central European mapping 


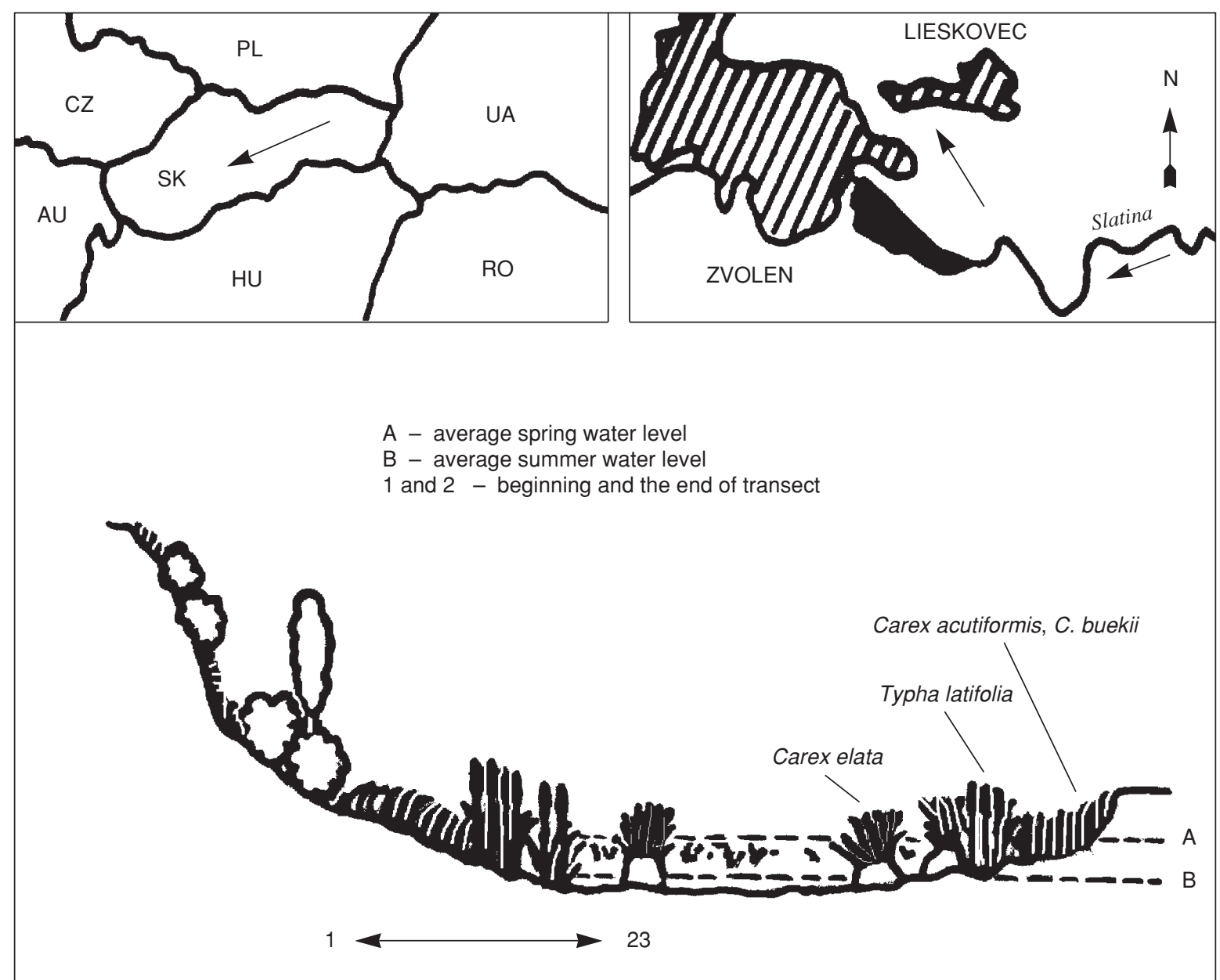

Fig. 1. Location and microtopography of the studied transect.

7481 A11; altitude $298 \mathrm{~m}$ above sea level). This locality belongs to the partial catchment area of the Slatina river (catchment area of Dunaj river). A location of the study site as well as transect topography is shown in the Figure 1. The study site is located in irrigated terrain depression (about $80 \mathrm{~m}$ wide and $300 \mathrm{~m}$ long) situated on the alluvial deposits of the brook Hučava. That terrain depression has been artificially closed by the system of dikes. There is $15-$ $20 \mathrm{~m}$ high fluvial terrace on the north border.

The area has a warm, lowland climate with the mean July temperature of $19.5-20.5^{\circ} \mathrm{C}$ (Tarábek 1980). The annual precipitations $710 \mathrm{~mm}$ were recorded in the Sliač climate station located about 10 km from study site (Šamaj 1980).

From the phytogeographical point of view, the study site belongs to the Carpaticum occidentale district, Praecarpaticum subdistrict (Futák 1966).

The vegetation forms the mosaic of marsh, aquatic and wet meadow plant communities of classes Phragmito-Magnocaricetea Klika in Klika et Novák 1941, Lemnetea de Bolós et Masclans 1955 and order Molinietalia Koch 1926. In areas with lower water table the aquatic vegetation is replaced by the communities of classes Bidentetea tripartitii R. Tx. et al. in R. Tx. ex von Rochow 1951.

\section{Soil sampling}

The soil samples for analyses were collected in depth of $15-25 \mathrm{~cm}$ in 1998. Three samples from main vegetation types were analysed using following methods:
- texture analysis (clay and silt by sedimentation method, sand was calculated as a complement),

- soil reaction $\left(\mathrm{pH}_{\mathrm{CaCl} 2}\right)$ by electrometric method,

- total organic carbon $\left(\mathrm{C}_{\mathrm{OX}}\right)$ by wet combustion using colorimetry for the $\mathrm{Cr}^{3+}$ determination,

- total nitrogen $\left(\mathrm{N}_{\mathrm{T}}\right)$ by LECO EP 228 analysator,

- available phosphorus $\left(\mathrm{P}_{\mathrm{M}}\right)$, potassium $\left(\mathrm{K}_{\mathrm{M}}\right)$, calcium $\left(\mathrm{Ca}_{\mathrm{M}}\right)$ and magnesium $\left(\mathrm{Mg}_{\mathrm{M}}\right)$ by Mehlich II method; AES $-\mathrm{ICP}$.

\section{Hydrology sampling}

The fluctuation of the water table was studied during the vegetation period (April-October). There were three gauges to find the fluctuation of the water table (A-C; Fig. 2). A microrelief was recorded in $0.5 \mathrm{~m}$ distance through the transect (Fig. 2).

Total rainfall was recorded daily and monthly at the Slovak Hydrometeorological Institute's station in Sliač located fewer than $10 \mathrm{~km}$ from the studied site.

\section{Vegetation sampling}

The field work was done during 1998-2000. The vegetation was analysed on a $22 \mathrm{~m}$ long and $5 \mathrm{~m}$ wide belt transect with the variation of moisture gradient. The beginning of the transect was not impacted by surface water while the end was submerged almost during the whole year. Particularly floristically well defined vegetation units were documented by phytosociological relevés, according to the 


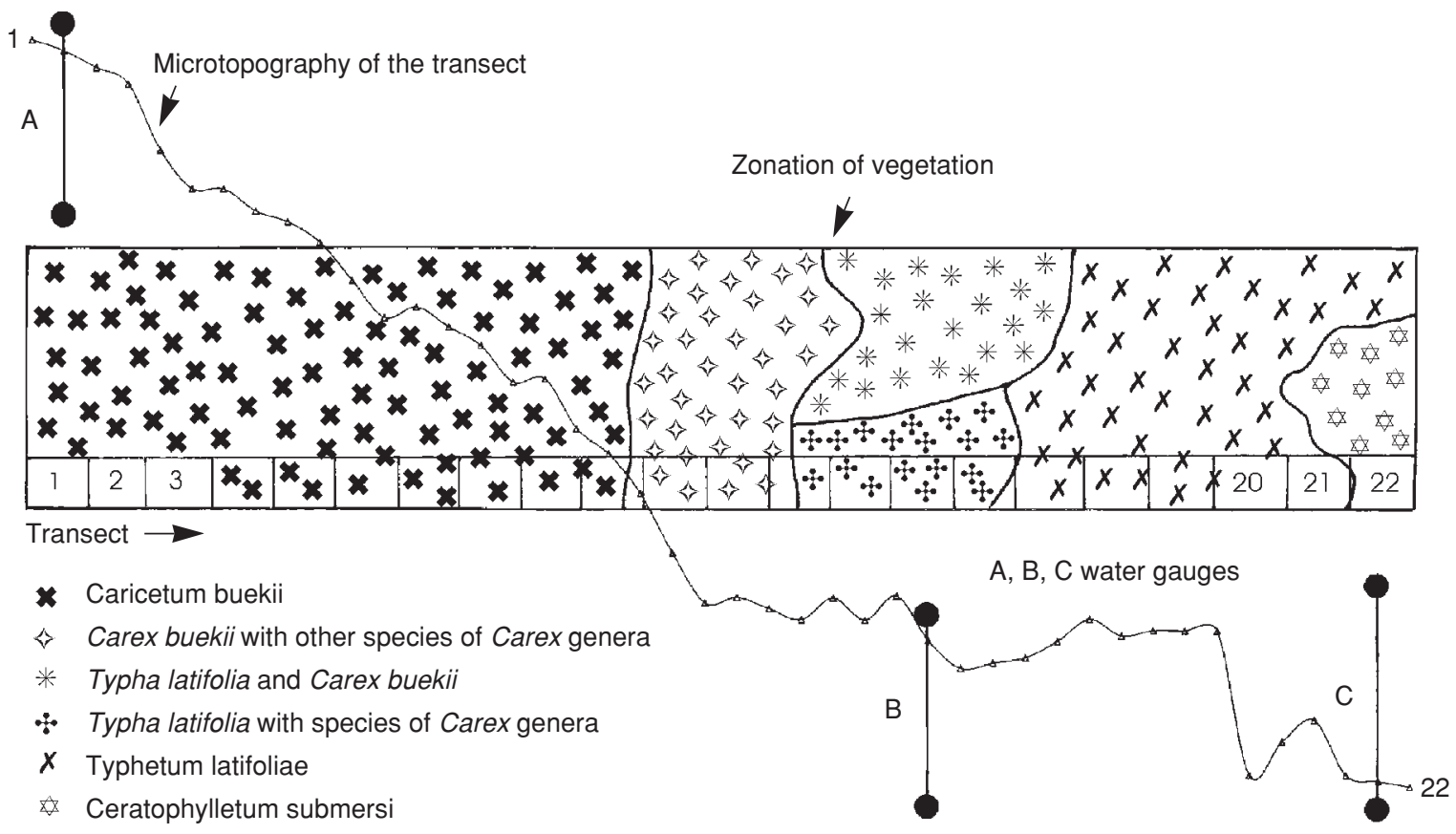

Fig. 2. Microtopography of the transect [the elevation between the beginning (1) and the end (22) of the transect is $67.3 \mathrm{~cm}$ ] and zonation of detected vegetation units on the transect in 1999.

Braun-Blanquet scale modified by Barkman et al. (1964). The borders between both, floristically well defined and transitional vegetation types were plotted in the map in 1999 (Fig. 2). The relative cover was estimated for each species along the whole transect in $1 \mathrm{~m}^{2}$ plots. At the same time presence (occurrence) of species was recorded in 0.25 $\mathrm{m}^{2}$ subplots. This sampling was performed at the end of June/beginning of July, and was repeated in September 2000 to record the seasonal dynamics of vegetation.

The nomenclature of plants follows Marhold and Hindák (1998). The term "ecophase" is used according to Hejný (1960). The names of vegetation units are presented with author's name and year of description when first mentioned.

\section{Data analysis}

The association between environmental and vegetation variables was expressed by correlation coeficient. The methods of indirect gradient analysis (Detrended Correspondence Analysis - DCA) were used to analyse the vegetation and ecological data. The programs CANOCO for Windows and STATISTICA were used for the calculation and graphic illustrations (ter Braak and Šmilauer 1998; Anonymus 2001).

\section{RESULTS AND DISCUSSION}

\section{Zonation of the vegetation}

Vegetation map of the transect is presented in Figure 2. Three well-defined vegetation units (Caricetum buekii, Typhetum latifoliae and Ceratophylletum submersi) and three transitional communities were detected.

Caricetum buekii Hejný et Kopecký in Kopecký et Hejný 1965 (Table 1, relevé 1) grows on the banks of running wa- ter, rarely in epilittoral and supralittoral of stagnating water. It forms mainly line stands poor in species with absolute dominance of Carex buekii. The fluctuation of the water table and dessication of soil in summer are typical for this community (cf. Kopecký and Hejný 1965; Valachovič 2001). Carex buekii root system penetrates in very deeply (up to $3 \mathrm{~m}$ ) in soil and plants have contact with ground water during almost all growing season (Kopecký and Hejný

TABLE 1. Phytosociological relevés of three well-defined vegetation units on the belt transect near Lieskovec village on 29. June 1999 (1 - Caricetum buekii, 2 - Typhetum latifoliae, 3 - Ceratophylletum submersi von Soó 1928).

\begin{tabular}{llccc}
\hline$* \quad$ Number of relevé & 1 & 2 & 3 \\
& Number of species & 2 & 13 & 7 \\
& Total cover $(\%)$ & 100 & 100 & 100 \\
& Relevé area $\left(\mathrm{m}^{2}\right)$ & 25 & 25 & 25 \\
\hline & Dominant species & & & \\
PM & Carex buekii & 5 &. &. \\
PM & Typha latifolia &. & 4 &. \\
LE & Ceratophyllum submersum & $\cdot$ & $\cdot$ & 5 \\
& Other species & & & \\
LE & Lemna trisulca & $\cdot$ & 3 & $2 \mathrm{a}$ \\
LE & Utricularia vulgaris agg. & $\cdot$ & + & + \\
PO & Callitriche palustris agg. & $\cdot$ & + & + \\
& Algae fil. & $\cdot$ & $2 \mathrm{a}$ & 3 \\
\hline
\end{tabular}

Legend:

* LE - Lemnetea de Bolós et Masclans 1955; O - other; PM - Phragmito-Magnocaricetea Klika in Klika et Novák 1941; PO - Potametea R. Tx. et Preising 1942

Species in one relevé only:

Batrachium trichophyllum (PO) 3: +; Carex acutiformis (PM) 2: +; Equisetum palustre $(\mathrm{O}) 2:+$; Galium aparine $(\mathrm{O}) 1:+;$ G. palustre $(\mathrm{PM}) 2:+$; Iris pseudacorus (PM) 2: +; Lemna minor (LE) 2: 3; Lycopus europaeus (PM) 2: +; Riccia fluitans (LE) 2: +; Solanum dulcamara (O) 2: +. 


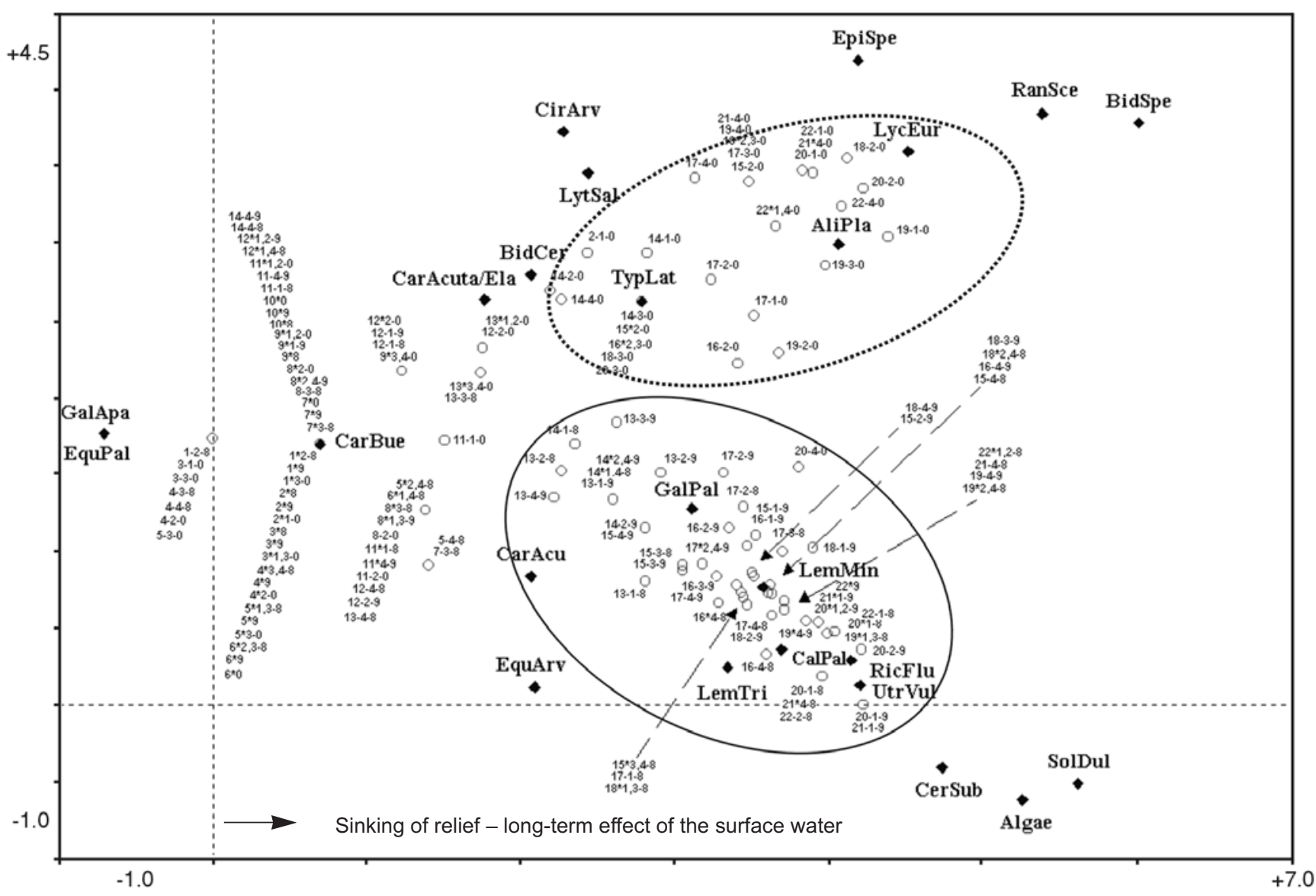

Fig. 3. DCA analysis of species presence in subplots in June/July 1998-2000 [total inertia: 5.50729; eigenvalues: 0.836 (axis 1), 0.517 (axis 2); cumulative percentage variance of species data: 15.2 (axis 1), 9.4 (axis 2)].

Legend: [examples - (21-4-0: $1 \mathrm{~m}^{2}$ plot number $-0.25 \mathrm{~m}^{2}$ subplot number - year of sampling, $\left.8-1998,9-1999,0-2000\right) ;\left(7 * 9\right.$ : all 0.25 $\mathrm{m}^{2}$ subplots within plot 7 - year), $\left(7 * 3-8\right.$ : all $0.25 \mathrm{~m}^{2}$ subplots except subplot 3 within plot $7-$ year). The $1 \mathrm{~m}^{2}$ plots are numbered from the beginning to the end of transect (1-22) and $0.25 \mathrm{~m}^{2}$ subplots are numbered from 1 to 4 within a $1 \mathrm{~m}^{2}$ plot]; open circle - subplot, solid rhomb - species, solid circle - combination subplot and species

Abbreviation of species: AliPla - Alisma plantago-aquatica, BidCer-Bidens cernua, BidSpe - Bidens sp. (includes B. frondosa and B. tripartita), CalPal - Callitriche palustris agg., CarAcu - Carex acutiformis, CarAcuta/Ela - Carex acuta and C. elata, CarBue - Carex buekii, CerSub - Ceratophyllum submersum, CirArv - Cirsium arvense, EpiSpe - Epilobium sp., EquArv - Equisetum arvense, EqiPal - Equisetum palustre, GalApa - Galium aparine, GalPal - Galium palustre, LemMin - Lemna minor, LemTri - Lemna trisulca, LycEur - Lycopus europaeus, LytSal - Lythrum salicaria, Ran Sce - Ranunculus sceleratus, RicFlu - Riccia fluitans, SolDul - Solanum dulcamara, TypLat - Typha latifolia, UtrVul - Utricularia vulgaris agg.

1965; Kopecký 1967). Typhetum latifoliae Lang 1973 (Table 1, relevé 2) occurs mainly in eulittoral of stagnating water or riparian zone of slowly running water. The biotopes are eutrophic, well supplied by nutrients. Typha latifolia is dominant, the other species are present according to the prevailing ecophase (cf. e.g. Balátová-Tuláčková et al. 1993; Rodwell 1995; Ot’ahelová 2001). Ceratophylletum submersi von Soó 1928 (Table 1, relevé 3) is a typical pleustophytic aquatic community, which grows in eutrophic and hypertrophic, moderately salline water. The stands are formed by submerged macrophyte Ceratophyllum submersum and some others aquatic species (cf. Ot’ahelová 1995). In general, Ceratophylletum submersi occurs in euthropic and moderately saline waters (Ot’ahelová 1995; Ot’ahelová and Husák 1985, Rodwell 1.c., Borhidi and Sánta 1999).

The vegetation follows the moisture gradient (Fig. 2, axis 1 in Fig. 3). Along transect, individual communities occur according to their requirements for the height and duration of flood. At the left side of Figures 2 and 3, respectively, species and communities are displayed, which prefer short- term and low-depth floods with a rapid decrease of the water table below the ground surface (Caricetum buekii; $\mathrm{Ca}$ rex buekii, Equisetum palustre, Galium aparine). Species and communities preferring longer-lasting floods with a higher water table (Typha latifolia, Carex acuta, C. acutiformis, C. elata) prevail in the middle part of the transect (central part of the Figs 2 and 3). Aquatic macrophytes (e.g. Lemna minor, L. trisulca, Ceratophyllum submersum) predominate in both permanently or long-term flooded parts of the transect (right side of Figs 2 and 3).

Correlation between elevation of individual plots (i.e. heigh and duration of flood) and the scores of subplots along the first DCA axis proved to be statistically significant (Fig. 4). A changing trend of point distribution on the graph at $10-15 \mathrm{~cm}$ above the lowest point of the transect reflects the boundary between the long-term and short-term flooding of the soil surface. It approximately corresponds to boundary between Caricetum buekii and Typhetum latofoliae at the distance of 12-14 $\mathrm{m}$ from the beginning of the transect and is formed by transitional plant communities dominated by Carex acuta, C. acutiformis, C. elata and Ty- 


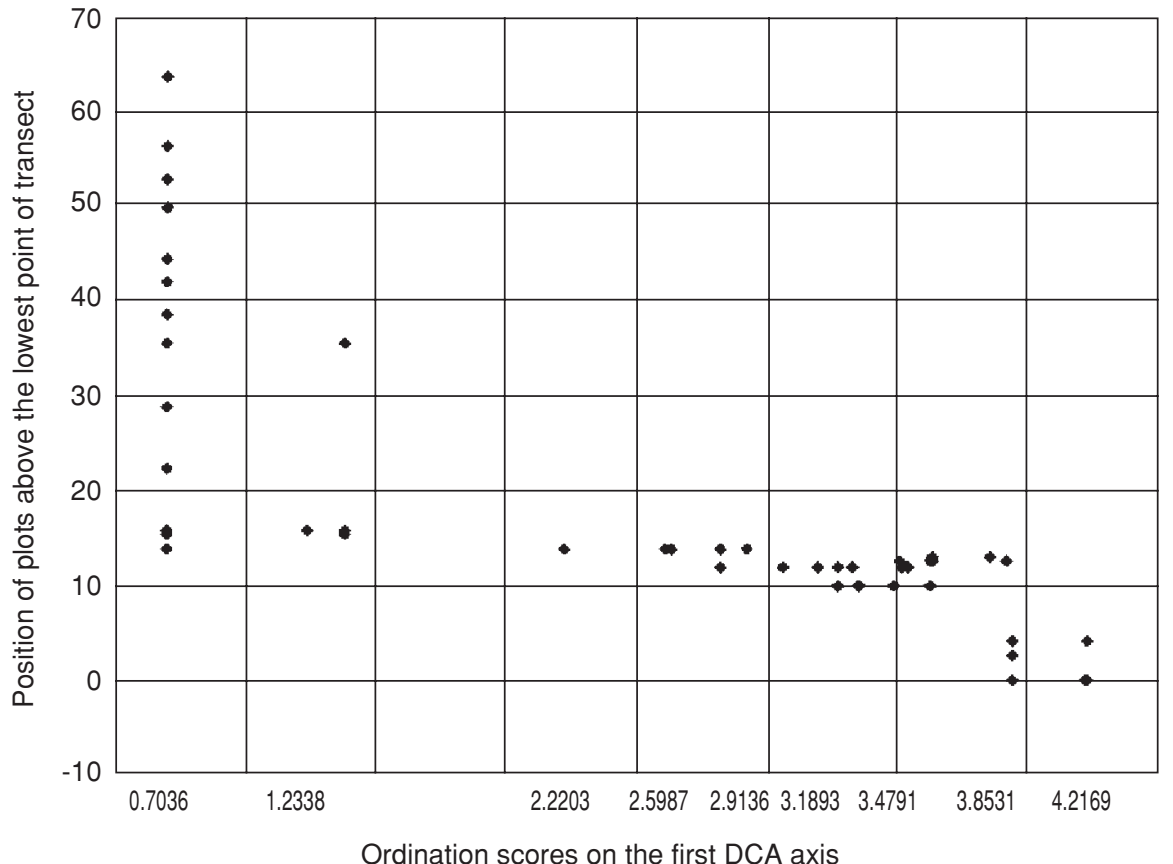

Fig. 4. Correlation between scores of subplots along first DCA axis and elevation of individual plots above the lowest transect point (Spearman $\mathrm{r}=-0.903496, \mathrm{p}<0.001)$. pha latifolia (Fig. 2). This results indicate that depth and duration of floods are very important ecological factors for zonation of wetland vegetation, wetland species composition and distribution. Similar findings were published by Henry et al. (1994), Casanova and Brock (2000), Jarolímek et al. (1999, 2000), Bouzille et al. (2001), Rheinhardt and Faser (2001), Riis and Hawes (2002).

\section{Soil analyses}

The soil is loamy with higher content of sand in Caricetum buekii or clay in Typhetum latifoliae. The soil reaction is moderately acid (Typhetum latifoliae and Ceratophylletum submersi) or alkaline (Caricetum buekii). The content of available nutrients, total organic carbon and nitrogen is very similar in all vegetation types. Bigger differences were found in the content of magnesium and total nitrogen, where Ceratophylletum submersi, had substantially higher values (Table 2). Similar soil characteristics of Ceratophylletum submersi were found in the Východoslovenská rovina lowland in the Eastern Slovakia (Ot’ahelová and Husák 1985).

\section{Hydrology}

Total precipitation was similar in 1998 and 1999 (723 $\mathrm{mm}$ and $706 \mathrm{~mm}$, respectively). In 2000 it was only 613 $\mathrm{mm}$. The maximum and minimum values of monthly precipitation in individual years were following: 1998 - min. 2 mm (February) and max. 148 mm (September), 1999 - 17
(September) and 179 (July), 2000 - 20 (August) and 112 (March). The least of precipitation felt during the vegetation period (April to September) in 2000 (only $232 \mathrm{~mm}$ ), which is only a half comparing with the previous years, $478 \mathrm{~mm}$ and $461 \mathrm{~mm}$, respectively (Fig. 5).

The water regime fluctuated during the observation periods. The least fluctuation during the growing season was recorded in 1999, and the biggest fluctuation in 2000, when the water table reached the lowest level (Figs 6a-c). It was due to the low precipitation during the growing season 2000. The water table fluctuation in the gauge located in the upper part of the transect (A) differed from that of the two gauges located in the lower part (B and C, Figs 2, $6 \mathrm{ac})$. The gauge $\mathrm{A}$ is influenced by ground water, whereas the other ones (B and C) are affected by the surface water in the lake. The influence of the precipitation is different as well. Short-term precipitation totals are more correlated with the water table in the gauge $\mathrm{A}$, the long-term ones correlate better with water table in the probes $\mathrm{B}$ and $\mathrm{C}(\mathrm{Ta}-$ ble 3 ). The values of a correlation coefficient in Table 3 are not significant $(\mathrm{p}<0.05)$ as the number of measurements was restricted.

\section{Species and vegetation dynamics Annual changes}

Annual changes of both species composition and cover on the transect are associated with the precipitation totals (mainly during the growing season from April to Septem-

TABLE 2. Results of soil analysis. Dry matter (DM), $98 \%$ - expressed as a percentage of 2 g sample; clay, dust, sand, $\mathrm{C}_{\mathrm{OX}}, \mathrm{N}_{\mathrm{T}} \mathrm{B} \%$ of $\mathrm{DM}$ and $\mathrm{P}_{\mathrm{M}}, \mathrm{K}_{\mathrm{M}}$, $\mathrm{Ca}_{\mathrm{M}}, \mathrm{Mg}_{\mathrm{M}} \mathrm{B} \mathrm{mg} \cdot \mathrm{kg}^{-1}$ of DM. A - the Carex buekii community, B - the Typha latifolia community, C - the Ceratophyllum submersum community.

\begin{tabular}{|c|c|c|c|c|c|c|c|c|c|c|}
\hline Plant community & $\mathrm{pH}\left(\mathrm{CaCl}_{2}\right)$ & Clay & Dust & Sand & $\mathrm{C}_{\mathrm{OX}}$ & $\mathrm{N}_{\mathrm{T}}$ & $\mathrm{P}_{\mathrm{M}}$ & $\mathrm{K}_{\mathrm{M}}$ & $\mathrm{Ca}_{\mathrm{M}}$ & $\mathrm{Mg}_{\mathrm{M}}$ \\
\hline A & 7.13 & 18.8 & 48 & 33.2 & 3.53 & 0.41 & 10.95 & 110.3 & 2023.2 & 323.1 \\
\hline B & 5.94 & 29.9 & 58.4 & 11.7 & 3.58 & 0.33 & 8.22 & 80.37 & 2101.8 & 374.9 \\
\hline $\mathrm{C}$ & 5.75 & 14 & 61.3 & 24.7 & 3.71 & 2.06 & 8.79 & 105 & 2651.4 & 470.5 \\
\hline
\end{tabular}




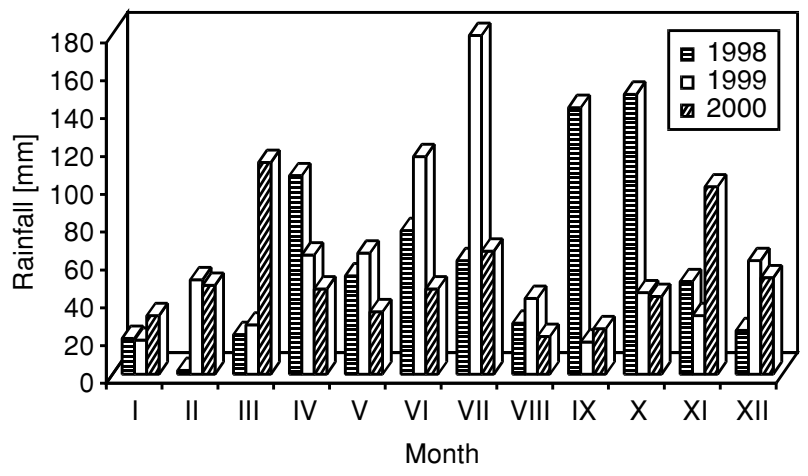

Fig. 5. Monthly precipitation in 1998-2000.

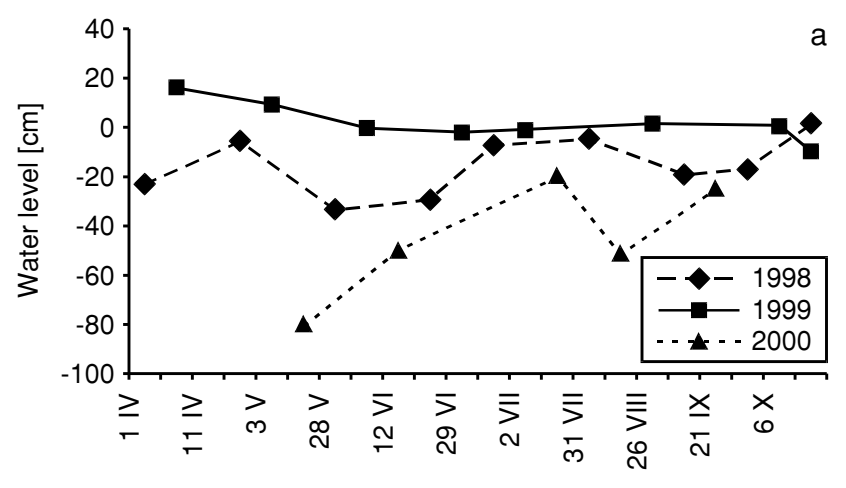

Date

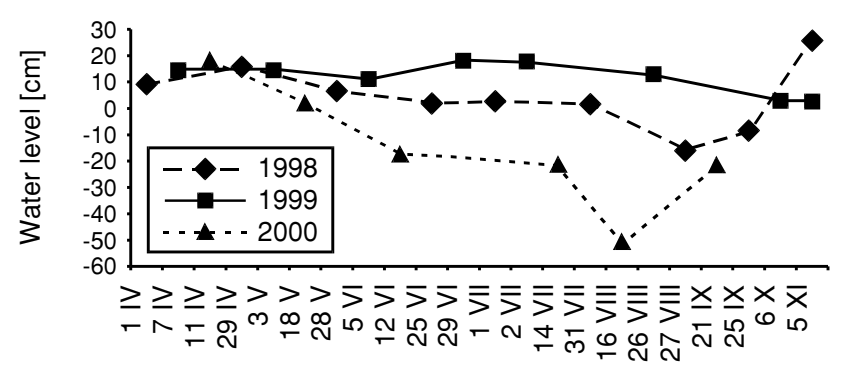

Date

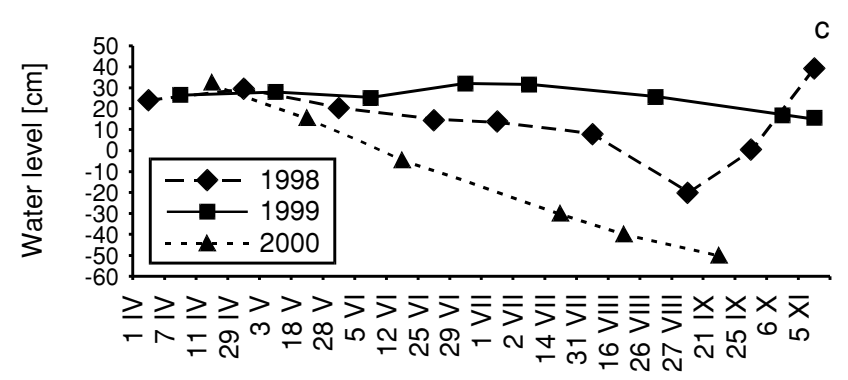

Date

Figs 6a-c. Seasonal fluctuation of water table in gauges A-C during the growing season 1998-2000.

ber), their temporal distribution, water table, as well as the existing vegetation type. The most pronounced ones occurred in 2000 comparing with the two preceding years (Fig. 3). Whereas the years 1998 and 1999 had similar precipitation totals during the growing season, during a very dry growing season in 2000 the absence of precipitation resulted in a pronounced decrease of water table (Figs 5, 6a-c). A different duration of individual ecophases affected the floristic composition of communities. Changes of species
TABLE 3. Correlation between precipitation totals (precipitation totals before measurement of the water table) and seasonal changes in the position of the water table (Pearson correlation coeficients; none of them was significant at $\mathrm{p}<0.05$ as the number of measurements was restricted).

\begin{tabular}{lccc}
\hline Period with precipitation & Gauge A & Gauge B & Gauge C \\
\hline 2 days & 0.31 & 0.07 & 0.12 \\
3 days & $\mathbf{0 . 5 7}$ & 0.09 & 0.04 \\
4 days & $\mathbf{0 . 6 0}$ & 0.12 & 0.10 \\
5 days & $\mathbf{0 . 5 8}$ & 0.05 & 0.02 \\
6 days & $\mathbf{0 . 5 0}$ & -0.25 & -0.34 \\
1 week & $\mathbf{0 . 5 9}$ & -0.14 & -0.25 \\
2 weeks & $\mathbf{0 . 5 3}$ & 0.03 & 0.04 \\
1 month & 0.45 & 0.30 & 0.36 \\
2 months & -0.18 & $\mathbf{0 . 5 1}$ & $\mathbf{0 . 6 5}$ \\
3 months & -0.07 & $\mathbf{- 0 . 6 3}$ & $\mathbf{- 0 . 5 2}$ \\
4 months & 0.23 & $\mathbf{- 0 . 7 0}$ & $\mathbf{- 0 . 6 5}$ \\
\hline
\end{tabular}

composition in Caricetum buekii were small (Fig. 3). On the other hand, considerable changes were recorded on plots with vegetation types with the predominance of aquatic macrophytes and Typha latifolia in combination with Carex species. In 1998-1999, water table was above the ground surface, hydrophytes were present in the second half of the transect, what caused ranking of these plots in the middle and right lower part of the ordination graph (Fig. 3, full line). On the other hand, the water table lowering in 2000 caused the absence of hydrophytes, and presence of Alisma plantago-aquatica, Bidens frondosa, B. tripartita and Ranunculus sceleratus. Thus these plots are situated in the middle and upper right part of the graph (Fig. 3, dashed line). The gradient displayed by the Axis 1 (Fig. 3) represents then the sinking relief and the long-term effect of the surface water, whereas the Axis 2 reflects the effect of the surface water on the vegetation at the time of sampling.

Along with changes in species composition, considerable changes in the species cover occurred. Figures 7a-d show the cover of species exhibiting the biggest changes. It is mainly the case of free floating species (Ceratophyllum submersum, Lemna minor, L. trisulca, Utricularia vulgaris agg.), Carex species (C. acuta, C. acutiformis, C. buekii, $C$. elata) and Typha latifolia.

The cover values of Carex buekii were quite equable on the first $11 \mathrm{~m}$ of the transect in 1998-2000. A strong decrease of cover between $11 \mathrm{~m}$ and $14 \mathrm{~m}$ in 2000 was probably caused by a long-term effect of flooding water in 19981999 (Figs 6b and 7a). This is not an optimum for Carex buekii and the Caricetum buekii community, where this sedge dominates (cf. Kopecký and Hejný 1965). The other tall sedges responded more positively (Figs $7 b-c)$. The situation is specific in case of Typha latifolia. This species prefers a long-term flood, littoral ecophase and it seems tolerant for wide range of water table (cf. e.g. Rodwell 1995; Ot’ahelová 2001). Despite this fact, an increasing trend was revealed only in 1999. In 2000, the cover of T. latifolia decreased considerably (Fig. 7d). However, this decrease was caused by the destruction of the stand by large amounts of snow during the winter season. The stand recovery was apparent only after the sink of the water table in the summer and autumn months, and it was mainly due to the generative propagation (Fig. 8). Aquatic macrophytes responded to dropping water table and/or absence of the surface water by reduced cover or even extinction. In 2000, only those were found (Lemna minor and very rare L. trisulca), which 

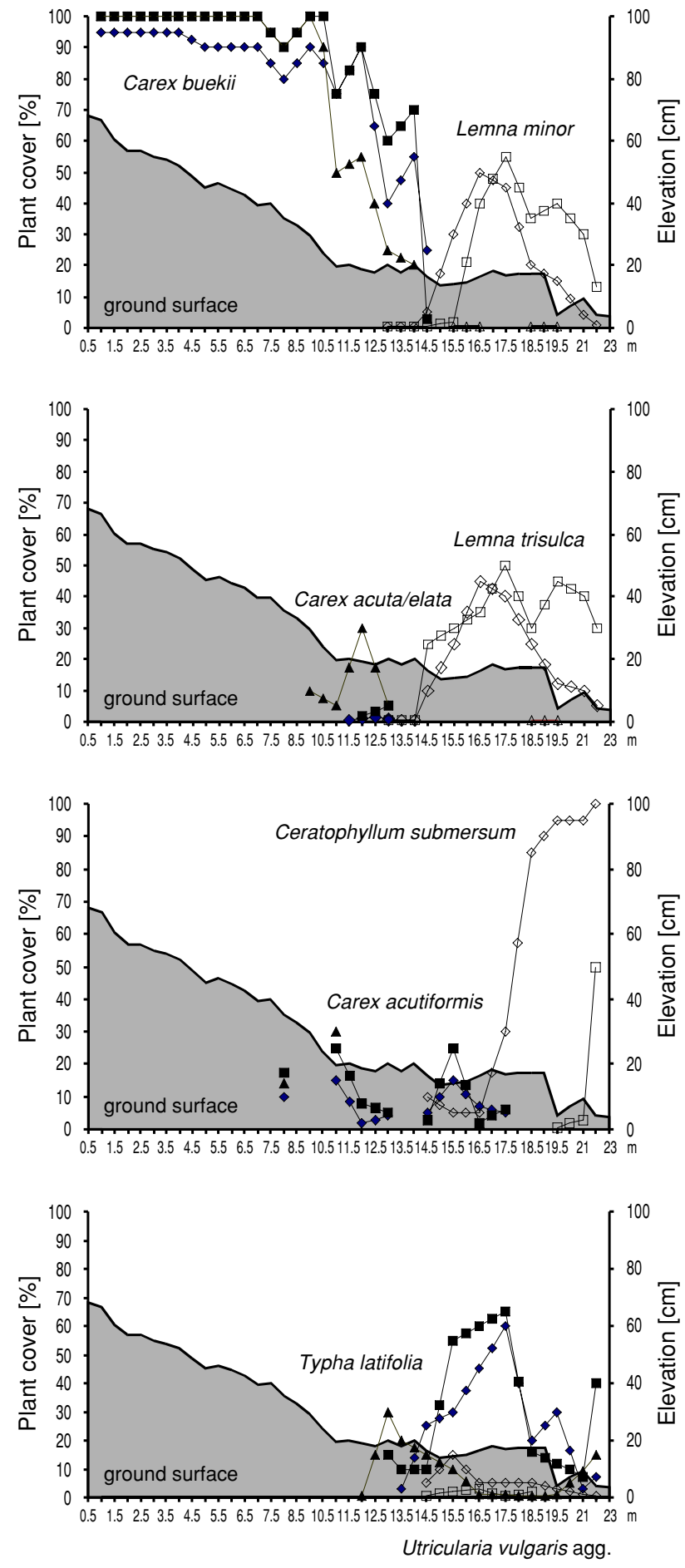

Fig. 7. a - cover of Carex buekii (full sign) and Lemna minor (empty sign) in 1998-2000 on the transect (1998 - rhomb, 1999 - square, 2000 - triangle); b - cover of Carex species (C. acuta and C. elata; full sign) and Lemna trisulca (empty sign) on the transect in 1998-2000 (1998 - rhomb, 1999 - square, 2000 - triangle); c - cover of Carex acutiformis (full sign) and Ceratophyllum submersum (empty sign) on the transect in 1998-2000 (1998 - rhomb, 1999 - square, 2000 - triangle); d - cover of Typha latifolia (full sign) and Utricularia vulgaris agg. (empty sign) on the transect in 1998-2000 (1998 - rhomb, 1999 - square, 2000 - triangle).

are capable to survive a short period in the limosal ecophase (cf. Hejný 1960). On the other hand, the species (Ceratophyllum submersum, Utricularia vulgaris agg.) requiring permanent presence of water above the ground surface (cf. Hejný 1960) retreated already in 1999, thus they were not recorded in 2000 (Figs. 7c-d).

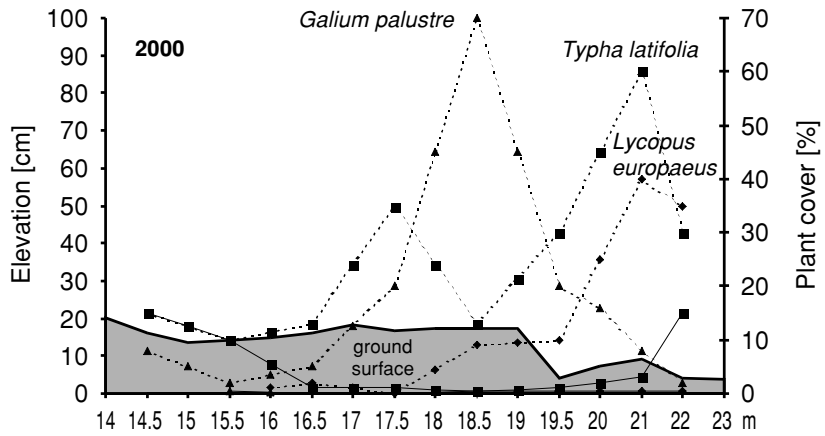

Fig. 8. Seasonal dynamic of three marsh species - Galium palustre as triangle, Lycopus europaeus as rhomb, Typha latifolia as square (the full line - VI. 2000, dashed line - IX. 2000) on the belt transect near Lieskovec village.

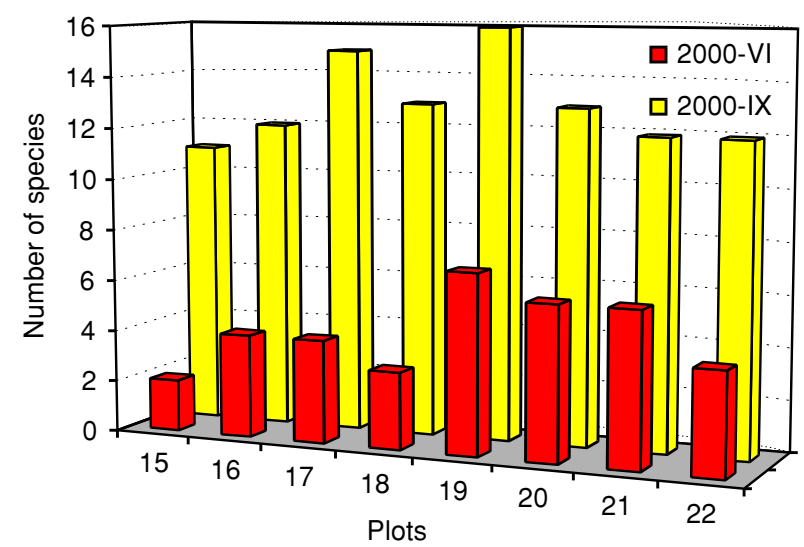

Fig. 9. Comparison of species diversity in plots situated in the lower transect in June and September 2000.

\section{Seasonal changes}

The decrease of the water table below the ground for a relatively long period within the growing season 2000 due to low precipitation (Figs. 6b-c), as well as the destruction of Typha latifolia stands in winter caused considerable vegetation changes in the second half of the transect (14-22 $\mathrm{m})$. Changes occurred not only among years, but also during the year 2000. Whereas the vegetation cover in this part of the transect was $2-35 \%$ at the beginning of the summer, in the late summer it ranged from 30 to $85 \%$. The free space was colonized by species, which are typical for littoral zone of pond (some of them were new for the studied transect) and the total number of species in these plots increased (Fig. 9). The rise in cover was most pronounced in three marsh species, Galium palustre, Lycopus europaeus and Typha latifolia (Fig. 8).

\section{ACKONOWLEDGEMENTS}

The author is grateful to J. Durkovič, D. Gömöry, M. Hrivnáková, M. Janišová, H. Ot’ahelová, B. Slobodník and K. Ujházy for many consultations, help in the field and English translation and corrections. Thanks go also to the stuff of the Slovak Hydrometeorological Institute in Banská Bystrica for providing monthly and daily precipitation data. 


\section{LITERATURE CITED}

ANONYMUS 2001. STATISTICA. System reference. StatSoft Inc., Tulsa.

BAATRUP-PEDERSEN A., RIIS T. 2003. Macrophyte diversity and composition in relation to substratum characteristics in regulated and unregulated Danish streams. Freshwater Biol. 48: 375-385.

BALÁTOVÁ-TULÁČKOVÁ E. 1968. Grundwasserganglinien und wiesengesellschaften (Vergleichende studie der wiesen aus Sudmähren und der SW-Slowakei). Acta Sci. Nat., Brno 2: $1-37$.

BALÁTOVÁ-TULÁČKOVÁ E., MUCINA L., ELLMAUER T., WALLNÖFER S. 1993. Phragmiti-Magnocaricetea. In: Die Pflanzengesellschaften Österreichs. Teil II. Natürliche waldfreie Vegetation. Grabher G., Mucina L. (eds). Gustav Fisher Verlag, Jena-Stuttgart-New York, pp. 79-129.

BANÁSOVÁ V., OŤAHELOVÁ H., JAROLÍMEK I., ZALIBEROVÁ M., HUSÁK Š. 1994a. Morava river floodplain vegetation in relation to limiting ecological factors. Ekológia 13: 247-262.

BANÁSOVÁ V., OŤAHEL'OVÁ H., JAROLÍMEK I., ZALIBEROVÁ M., HUSÁK Š. 1994b. The influence of important environmental factors on the vegetation structure in the alluvial plain of the Morava river. Ekológia, Suppl. 1 (1994): 125-133.

BARKMAN J.J., DOING H., SEGAL S. 1964. Kritische Bemerkungen und Vorschläge zur quantitativen Vegetationsanalyse. Acta Bot. Neerl. 13: 394-419.

BERLIN G.A.I., LINUSSON A.C., OLSSON E.G.A. 2000. Vegetation changes in semi-natural meadows with unchanged management in southern Sweden, 1965-1990. Acta Oecol. Int. J. Ecol. 21: 135-138.

BLEDSOE B.P., SHEAR T.H. 2000. Vegetation along hydrologic and edaphic gradients in a North Carolina coastal plain creek bottom and implications for restoration. Wetlands 20: 126-147.

BORHIDI A., SÁNTA A. (eds) 1999. Vörös könyv Magyarország növénytársulásairól. 1. Természet BÚVÁR Alapítvány Kiadó, Budapest, 362 pp. (in Hungarian)

BOUZILLE J.B., KERNEIS E., BONIS A., TOUZARD B. 2001. Vegetation and ecological gradients in abandoned salt pans in western France. J. Veg. Sci. 12 (2): 269-278.

BUDELSKY R.A., GALATOWITSCH S.M. 2000. Effect of water regime and competition on the establishment of a native sedge in restored wetlands. J. Appl. Ecol. 37: 971-985.

BUSCH D.E., LOFTUS W.F., ORON L.B. jr. 1998. Long-term hydrologic effects on marsh plant community structure in the Southern Everglades. Wetlands 18: 230-241.

CASANOVA M.T., BROCK M.A. 2000. How do depth, duration and frequency of flooding influence the establishment of wetland plant communities? Pl. Ecol. 147: 237-250.

CLARKE E., BALDWIN A.H. 2002. Responses of wetland plants to ammonia and water level. Ecol. Engin. 18: 257-264.

DAVID P.G. 1996. Changes in plant communities relative to hydrologic condition in the Florida Everglades. Wetlands 16: 15-23.

DE KLERK P., JANSSEN C.R., JOOSTEN J.H.J. 1997. Patterns and processes in natural wetland vegetation in the Dutch fluvial area: A palaeoecological study. Acta Bot. Neerl. 46: 147-159.

FUTÁK J. 1966. Fytogeografické členenie Slovenska. In: Flóra Slovenska I. Futák J. (ed.). Vydavatelsstvo Slovenskej akadémie vied, Bratislava, pp. 533-538. (in Slovak)

GALATOWITSCH S.M., WHITED D.C., LEHTINEN R., HUSVETH J., SCHIK K. 2000. The vegetation of wet meadows in relation to their land-use. Environm. Monitoring and Assessment 60: 121-144.

HANSEL-WELCH N., BUTLER M.G., CARLSON T.J., HANSON M.A. 2003. Changes in macrophyte community structure in Lake Christina (Minnesota), a large shallow lake, following biomanipulation. Aquatic Bot. 75: 323-337.
HEJNÝ S. 1960. Ökologische Charakteristik der Wasser- und Sumpfpflanzen in den slowakischen Tiefebenen (Donau- und Theissgebieten). Vydavatel'stvo SAV, Bratislava.

HENRY C.P., BORNETTE G., AMOROS C. 1994. Differentialeffects of floods on the aquatic vegetation of braided channels of the Rhone river. J. N. Amer. Benthological Soc. 13: 439-467.

HUMPHRIES P., BALDWIN D.S. 2003. Drought and aquatic ecosystems: an introduction. Freshwater Biol. 48: 1141-1146.

ISACHENKO G.A. 1996. Lake Ladoga Region: Human impacts and recent environmental changes. Hydrobiologia 322: 217-221.

JAROLÍMEK I., BANÁSOVÁ V., OŤAHELOVÁ H. 1999. Effects of ecological gradients on the vegetation zonation of the emergent bank. Biologia 54: 405-413.

JAROLÍMEK I., BANÁSOVÁ V., OŤAHELOVÁ H. 2000. Changes in alluvial grassland vegetation in relation to flood dynamics and soil moisture. Ekológia 19: 39-53.

JAROLÍMEK I., BANÁSOVÁ V., OŤAHELOVÁ H., ZALIBEROVÁ M. 2001a. The dynamics of the emergent bank vegetation of the meander after the reinstatement of its connection with the river. Biologia 56: 77-83.

JAROLÍMEK I., BANÁSOVÁ V., OŤAHEL'OVÁ H., ZALIBEROVÁ M. 2001b. Nine year succession of the herbaceous floodplain vegetation in the Morava river. Ekológia 20 (Suppl. 2): 92-100.

KOPECKÝ K., HEJNÝ S. 1965. Allgemeine Charakteristik der Pflanzengesellschaften des Phalaridion arundinaceae-Verbandes. Preslia 37: 53-78.

KOPECKÝ K. 1967. Mitteleuropäische Flussröhrichtgesellschaften des Phalaridion arundinaceae-Verbandes. Limnologica 5: 39-79.

LEENDERTSE P.C., ROOZEN A.J.M., ROZEMA J. 1997. Long-term changes (1953-1990) in the salt marsh vegetation at the Boschplaat on Terschelling in relation to sedimentation and flooding. Pl. Ecol. 132: 49-58.

MARHOLD K., HINDÁK F. (eds) 1998. Zoznam nižších a vyšších rastlín Slovenska. Veda, Bratislava. (in Slovak)

MESLEARD F., LEPART J., GRILLAS P., MAUCHAMP A. 1999. Effects of seasonal flooding and grazing on the vegetation of former ricefields in the Rhone delta (Southern France). Pl. Ecol. 145: 101-114.

MOORE H.H., NIERING W.A., MARCISANO L.J., DOWDELL M. 1999. Vegetation change in created emergent wetlands (1988-1996) in Connecticut (USA). Wetlands Ecol. Managem. 7: 177-191.

OŤAHELOVÁ H. 1995. Lemnetea de Bolós et Masclans 1955. In: Rastlinné spoločenstvá Slovenska 1. Pionierska vegetácia. Valachovič M. (ed.). Veda, Bratislava, pp. 129-150. (in Slovak)

OŤAHELOVÁ H. 2001. Phragmition comunnis Koch 1926. In: Rastlinné spoločenstvá Slovenska 3. Vegetácia mokradí. Valachovič, M. (ed.). Veda, Bratislava, pp. 63-86. (in Slovak)

OŤAHELLOVÁ H., HUSÁK Š. 1985. Vodná a močiarna vegetácia. In: Vegetačné pomery južnej časti Východoslovenskej nížiny. Špániková A. (ed.). Acta Bot. Slov., A 8: 44-115. (in Slovak)

OWEN C.R. 1998. Hydrology and history: land use changes and ecological responses in an urban wetland. Wetland Ecol. Managem. 6: 209-219.

PAHL-WOSTL C., HOFF H., MEYBECK M., SOROOSHIAN S. 2002. The role of global change research for aquatic sciences. Editorial. Aquatic Sci. 64: 4-6.

PAPASTERGIADOU E., BABALONAS D. 1993a. The relationships between hydrochemical environmental-factors and the aquatic macrophytic vegetation in stagnant waters I. Water-quality and distribution of aquatic associations. Arch. Hydrobiol. 4, Suppl. 90: 475-491.

PAPASTERGIADOU E., BABALONAS D. 1993b. The relationships between hydrochemical environmental-factors and the aquatic macrophytic vegetation in stagnant waters II. Evaluation of plant associations indicative value. Arch. Hydrobiol. 4, Suppl. 90: 493-506. 
PETEET D., ANDREEV A., BARDEEN W., MISTRETTA F. 1998. Long-term Arctic peatland dynamics, vegetation and climate history of the Pur-Taz region, Western Siberia. Boreas 27: $115-126$

RHEINHARDT R.D., FASER K. 2001. Relationship between hydrology and zonation of freshwater swale wetlands on Lower Hatteras Island, North Carolina, USA. Wetlands 21: 265-273.

RIIS T., HAWES I. 2002. Relationship between water level fluctuations and vegetation diversity in shallow water of New Zealand lakes. Aquatic Bot. 74: 133-148.

RINTANEN T. 1996. Changes in the flora and vegetation of 113 Finnish lakes during 40 years. Ann. Bot. Fenn. 33: 101-122.

RODWELL J.S. (ed.) 1995. British Plant Communities. Volume 4. Aquatic communities, swamps and tall-herb fens. Cambridge University Press.

SANCHEZ J.M., OTERO X.L., IZCO J. 1998. Relationships between vegetation and environmental characteristics in a saltmarsh system on the coast of Northwest Spain. Pl. Ecol. 136: $1-8$.

SCHAMINÉE J.H.J., VAN KLEY J.E., OZINGA W.A. 2002. The analysis of long-term changes in plant communities: case studies from the Netherlands. Phytocoenologia 32: 317-335.

SIMAS T., NUNES J.P., FERREIRA J.G. 2001. Effects of global climate change on coastal salt marshes. Ecol. Modelling 139: $1-15$.

SOLIŃSKA-GÓRNICKA B., SYMONIDES E. 2001. Long-term changes in the flora and vegetation of lake Mikołajskie (Poland) as a result of its eutropication. Acta Soc. Bot. Pol. 70: 323-334.
ŠAMAJ F. 1980. Zrážky. In: Atlas Slovenskej socialistickej republiky. Mazúr E. (ed.). Slovenská akadémia vied \& Slovenský úrad geodézie a kartografie, Bratislava, pp. 62. (in Slovak)

ŠEFFER J., STANOVÁ V., VICENÍKOVÁ A. 1999. Impact of floods and management on composition of meadow communities. In: Morava river floodplain meadows - Importance, restoration and management. Šeffer, J., Stanová, V. (eds). DAPHNE - Centre for applied ecology, Bratislava, pp. 103-117.

TARÁBEK K. 1980. Klimatogeografické typy. In: Atlas Slovenskej socialistickej republiky. Mazúr E. (ed.). Slovenská akadémia vied \& Slovenský úrad geodézie a kartografie, Bratislava, pp. 64. (in Slovak)

TER BRAAK C.J.F., ŠMILAUER P. 1998. CANOCO reference Manual and User's Guide to Canoco for Windows (Software for Canonical Community Ordination, version 4). Centre of Biometry, Wageningen.

VALACHOVIČ M. 1995. Zonácia halofytnej vegetácie na slanisku pri Tvrdošovciach (Západné Slovensko). Bull. Slov. Bot. Spoločn. 17: 27-39. (in Slovak)

VALACHOVIČ M. 2001. Nasturtio-Glycerietalia Pignatti 1953. In: Rastlinné spoločenstvá Slovenska 3. Vegetácia mokradí. Valachovič, M. (ed.). Veda, Bratislava, pp. 128-147. (in Slovak)

VAN DER KNAAP W.O., VAN LEEUWEN J.F.N. 1997. Late Glacial and early Holocene vegetation succession, altitudinal vegetation zonation, and climatic change in the Serra da Estrela, Portugal. Rev. Paleobot. Palynol. 97: 239-285.

VAN DER VALK A.G., SQUIRES L., WELLING C.H. 1994. Assessing the impact of an increase in water-level on wetland vegetation. Ecol. Appl. 4: 525-534. 